\title{
THE RIGHT OF COURT TO CHANGE A CATEGORY OF CRIME TO LESS SEVERE
}

\begin{abstract}
This article examines the positions of Part 6 of Article 15 of the Criminal Code of the Russian Federation (CCRF) on authority of the courts to lower the category of a crime, as well as the grounds and conditions for such decision. The author gives attention to the wide boundaries of the court's discretion in making a decision in accordance with the Part 6 of Article 15, and analyzes law enforcement practice and clarification of the Supreme Court of the Russian Federation on this issue. This work presents criticism on the Federal Law No. 420-FZ regarding the amendment it made to the Part 6 of Article 15, which contains corruptogenic factors and contradicts Article 10 of the Constitution of the Russian Federation. The scientific novelty lies in the attempt to attract the attention of scientists and practicians to the problematic issues emerging in relation to the application of Part 6 of the Article 15, particularly: which procedural document should reflect the court's decision to lower the category of a crime, and which juridical consequences could follow the court's decision to change the category of a committed crime.
\end{abstract}

Keywords: Aggravating circumstances, mitigating circumstances, separation of powers, court decision, conciliation of parties, factual circumstances, conditions and grounds, crime category, categorization of crime, interpretation.

Аннотация: В статье рассматриваются положения ч. $6 \mathrm{~cm} .15$ УК РФ о правомочии суда изменять категорию преступления на менее тяжкую, основания и условия для принятия такого решения, обращается внимание на широкие пределы судейского усмотрения при принятии решения судьей (судом) в соответствии с ч. $6 \mathrm{~cm}$. 15 УК РФ, анализируются правоприменительная практика и разъяснения Верховного Суда РФ по данному вопросу. Кроме этого, в статье критикуется Федеральный закон N 420-ФЗ в отношении дополнения им ст. 15 УК РФ частью шестой, которая содержит коррупииогенные факторы и противоречит ст. 10 Конституции РФ. Методологической основой исследования является общенаучный диалектический метод познания, а также формально-логический, системно-структурный метод, метод аналогии и статистического анализа. Новизна исследования заключается в том, чтобы обратить пристальное внимание ученых и практических работников на проблемные вопросы, возникающие в связи с применением ч. $6 \mathrm{~cm} .15$ УК РФ, в частности: в каком проиессуальном документе должно быть отражено решение суда об изменении категории преступления и какие юридические последствия влечет за собой изменение судом категории совершенного преступления.

Ключевые слова: Категория преступления, условия и основания, фактические обстоятельства, примирение сторон, судебное решение, разделение властей, смягчающие обстоятельства, отягчающие обстоятельства, катигоризация преступлений, интерпретация.

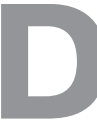

ifferentiation of crimes on categories is an essential process allowing choosing such punitive measures, which are commensurate with the gravity of offense. N.A. Kolokolov points out that category of a concrete crime is a variable value: it is an instrument in the hands of the legislator, with which the legislator tries to concretize the current criminal policy [1].

Since the adoption of the 1996 Criminal Code the category of crime had not depended on the will of the judge and automatically had determined statutory consequences. But as a result of changes made in the criminal code, the court has acquired the right to change crime category.

According to part 6 of article 15 of the Criminal Code of the Russian Federation the court has the right to change the category of crime to less severe in the presence of mitigating circumstances and the absence of aggravating circumstances, but not more than one category taking into account the actual circumstances of the offense and the degree of public danger. Thus, Federal Law N 420-FL gives the federal court of general jurisdiction, as well as the justice of the peace the opportunity in their sole discretion to change administration of the federal law.

Circumstances which are mentioned in part 6 of article 15 of the Criminal Code can be divided into conditions and grounds. Conditions can be general, which do not depend on the category of crime, and special, which are associated with a specific category of crime. General conditions for application of the rule provided by part 6 of article 15 of the Criminal Code are the following:

1) presence of mitigating circumstances,

2) absence of aggravating circumstances.

In terms of part 6 of article 15 of the Criminal Code we can identify the following special conditions: 


\section{Право и политика $11(191) \cdot 2015$}

1) the crime should be of a little gravity, average gravity and grave. In case of committing crime of a little gravity and the presence of all conditions and grounds for applying the rule provided by Part 6 of Article 15 of the Criminal Code, the court should consider the possibility of applying Part 2 of Article 14 of the Criminal Code ( The commission of an act, or an inaction, although formally containing the indicia of any act provided for by this Code, but which, by reason of its insignificance, does not represent a social danger that is, which caused no harm and has not created a treat of damage to a person, society, or the state, shall not be deemed a crime);

2) prescription of a penalty for committing crime of average gravity, grave or especially grave crime not exceeding three, five and seven years of imprisonment, respectively.

There are two grounds for application of part 6 of article 15 of the Criminal Code:

1) exceptional factual circumstances of the offense;

2) exceptional degree of public danger of the crime.

The factual circumstances of the offense are any circumstances related to the determination of the facts of life, the phenomena of reality forming in this particular case the factual basis for the application of this rule.

The degree of public danger of crime is determined according to specific circumstances of the offense, in particular the dimension of harm and the gravity of consequences, the degree of realization of the criminal intent, the way of committing crime, the role of the accused in the crime committed in complicity, the existence in the crime circumstances entailing more severe punishment in compliance with the sanctions of the Criminal Code of the Russian Federation[2]. According to A.A. Tolkachenko the issue of changing the category of crime should be exception[3]. So the factual circumstances of the crime and the degree of its public danger describe the exceptionality of this issue.

The supplement to the article 15 was not accepted unequivocally by scholars and practitioners. Some researchers responded positively to this change, while the majority of them maintained a negative attitude.

Thus, A. Yepikhin believes that giving the court additional opportunity not to deprive the perpetrator of liberty, release him or provide delay of a penalty can reduce the number of prisoners serving sentences of deprivation of liberty and other convicted by a court judgment[4, c. $105-108$.].

But the majority of scholars opposed to changing the category of crime by court and criticized this provision. Thus, according to V. Malkov in this case the court acquires the right of legislator, which is contrary to the Constitution of the Russian Federation as changing category of a crime goes beyond the authority of the court as the body of justice[5, c. $36-39$.]. Some scholars believe that such innovation prejudices not only the institute of the categorization of crimes in the Russian criminal law, but also the institute of public danger[6, c. $679-684$.]; it is contrary to the principles of legality and equity, and has negative impact on the objectivity of the decisions handed down by the court[7].

Firstly, provisions of part 6 of article 15 of the Criminal Code, in essence, give judges the right to go beyond their jurisdiction. In the restricted sense justice is the function of the court on consideration and disposition of civil, criminal, and administrative cases with the participation of the parties and other stakeholders of the legal procedure[8, c. 14.].

Secondly, these provisions are groundless for the reason that criminal and criminal procedure legislations do not establish legal instruments for their implementation, which objectively creates opportunities for discretion of judge. This indicates on the presence of factors of corruption[9]. This is contrary to article 10 of the Constitution of the Russian Federation, according to which the state power in the Russian Federation is based on the separation of legislative, executive, and judicial branches and the bodies of legislative, executive and judicial powers are independent.

In theory and in court practice there is no clarity on the basis of what factual circumstances of the crime and the degree of public danger the judge can (or should) make a decision of changing crime category.

The circumstances mitigating the punishment cannot be of significance in their own right, while the judge makes a decision to change the category of crime. So, we should agree with V. Pavlov who thinks that the basis for application of part 6 of article 15 of the Criminal Code is not the presence of mitigating and the absence of aggravating circumstances, but the factual circumstances of the offense and the degree of its public danger. The judge should indicate in the sentence, which factual circumstances he/she takes into consideration while making decision to change the category of the crime. Currently, judges unfoundedly interpret the presence of mitigating circumstances as a basis for changing category of the crime. Therefore, this issue needs clarification of the Plenum of the Supreme Court of Russian Federation[10].

Another important practical question relates to the procedural document, in which the court should indicate decision of changing category of crime. Federal law N 420-FL supplemented part 1 of article 299 of the Code of Criminal Procedure by clause 6.1., according to which in the judgment the court should decide whether there are grounds for changing crime category in accordance with part 6 of article 15 of the Criminal Code. From this we 
can draw a conclusion that the decision to change crime category should be made after the examination of all the circumstances of the case and prescription of a penalty. M. Gorbatov and G. Rusman have noted that the decision for applying part 6 of article 15 of the Criminal Code should be in the descriptive-motivational part of the judgment and, in case of making such decision, it should also be stated in the resolutive part of the judgment, since it entails substantial criminal consequences[11, c. 45].

Although it is not directly mentioned in articles 308 , 309 of Code of Criminal Procedure, it would be relevant to include the decision of changing the category of a crime in the resolutive part of the judgment. This approach is practiced by the regional courts of Russia[12].

The next question arising from part 6 of article 15 relates to the actions of the court in case of reconciliation of parties.

This problem was solved after the adoption of $\mathrm{N} 19$ Resolution of the Plenum of the Supreme Court. According to Clause 26 of Resolution of the Plenum of the Supreme Court N 19 "On Application By Courts of Legislation Regulating the Grounds and Procedures for the Relief from Criminal Liability" court releases the convict from punishment, when changing crime category in accordance with part 6 of article 15 of the Criminal Code and there are grounds provided by articles 75, 76, 76.1 and 78 of the Criminal Code. Thus, if the court changes the category of a crime and the parties were reconciled, the court should pass a sentence with imposition of penalty and exemption from penalty. (clause 2, part 5, article 302 Code of Criminal Procedure).

Consequently, categorization of crime can be formal (legally defined) and factual (established by the court). Both of them entail equal consequences. According to interpretation of the Supreme Court of the Russian Federation the changing of category of crime by court necessarily entails such legal consequences as, in particular, the change in calculation of the limitation period, the regime of serving the sentence, the definition of the type of recidivism of crime, the possibility of exemption from criminal liability in connection with reconciliation with the victim[13]. So after the changing of the crime category from grave to crime of average gravity, court can exempt offender from criminal liability in connection with the reconciliation of the parties after execution of the terms provided by article 25 of Code of Criminal Procedure of the Russian Federation.

\section{Библиография:}

1. Колоколов Н. А. Категория преступления-величина переменная? - Мировой судья. 2012. - N 7.

2. Дядькин Д. С. Уголовно-правовые проблемы применения ч. 6 ст. УК РФ. - СПС «КонсультантПлюс»

3. Толкаченко А. А. Изменение судом категории преступления на основании ч. 6 ст. 15 УК РФ. URL: http://livelawyer.m/ ugolovnyj-protsess/pravosudie/item/654-izmenenie-sudom-kategorii-prestupleniya-na-osnovanii-ch-6-st-15-uk-rf (дата обращения: 23.10.2015).

4. Епихин А. Ю. Расширение полномочий суда на понижение категории преступления: уголовно-правовой и уголовнопроцессуальный аспекты. Юридическая наука и правоохранительная практика, 2012. N 2.

5. Малков В. Право суда на изменение категории преступления. - Законность. 2013. - N 11.

6. Матюшов А. М., Шеслер А. В. Недопустимость изменения категории преступления в рамках статьи 15 Уголовного кодекса Российской Федерации. Новосибирск: Материалы IV студенческой международной заочной научно-практической конференции, 2012.

7. Никулин С. Вопросы применения ч. 6 ст. 15 УК РФ. Уголовное право, 2012. - N 5; Мингалимова М. Неясность в практическом применении новых положений Общей части УК. Законность. - 2013. - N 3; Виницкий Л., Кубрикова М. Возможно ли изменение категории преступления при рассмотрении уголовных дел в порядке гл. 40.1 УПК РФ? Законность, 2013. - N 8; Малков В. Право суда на изменение категории преступления. Законность. - 2013. - N 11; Трофимова Г.А. Расширение границ принципа судейского усмотрения. Российский судья. - $2014 .-\mathrm{N} 1$. СПС «КонсультантПлюс».

8. Строгович М. С. Курс советского уголовного процесса: В 2 т. - Москва: Т. І., 1970.

9. Малков В. П. Право суда на изменение категории преступления. - СПС «КонсультантПлюс».

10. Хайдаров А. А. Право суда изменить категорию преступления на менее тяжкую. - СПС «КонсультантПлюс».

11. Горбатова М., Русман Г. Изменение категории преступления: проблемы правоприменения и обратная сила уголовного закона. - Уголовное право. - 2012. - N 5.

12. Анализ судебной практики применения судами области положений ч. 6 ст. 15 УК РФ об изменении категории преступления. Официальный сайт Тверского областного суда. URL: http://oblsud.twr.sudrf.ru/modules.php?name=press dep\&op=3\&did=63 (дата обращения: 23.10.2015).

13. Ответы на вопросы, поступившие из судов, по применению Федеральных законов от 7 марта 2011 г. N 26 -Ф3 «О внесении изменений в Уголовный кодекс Российской Федерации» и от 7 декабря 2011 г. N 420-Ф3 «О внесении изменений в Уголовный кодекс Российской Федерации и отдельные законодательные акты Российской Федерации» (утв. Президиумом Верховного Суда РФ 27 июня 2012 г.). СПС «КонсультантПлюс». 
DOI: 10.7256/1811-9018.2015.11.16824

При цитировании этой статьи сноска на dоі обязательна

\section{Право и политика 11 (191) 2015}

\section{References (transliterated):}

1. Kolokolov N. A. Kategoriya prestupleniya-velichina peremennaya? - Mirovoi sud'ya. 2012. - N 7.

2. Dyad'kin D. S. Ugolovno-pravovye problemy primeneniya ch. 6 st. UK RF. - SPS "Konsul'tantPlyus"

3. Tolkachenko A. A. Izmenenie sudom kategorii prestupleniya na osnovanii ch. 6 st. 15 UK RF. URL: http://livelawyer.m/ugolovnyjprotsess/pravosudie/item/654-izmenenie-sudom-kategorii-prestupleniya-na-osnovanii-ch-6-st-15-uk-rf (data obrashcheniya: 23.10.2015).

4. Epikhin A. Yu. Rasshirenie polnomochii suda na ponizhenie kategorii prestupleniya: ugolovno-pravovoi i ugolovno-protsessual'nyi aspekty. Yuridicheskaya nauka i pravookhranitel'naya praktika, 2012. N 2.

5. Malkov V. Pravo suda na izmenenie kategorii prestupleniya. - Zakonnost'. 2013. - N 11.

6. Matyushov A. M., Shesler A. V. Nedopustimost' izmeneniya kategorii prestupleniya v ramkakh stat'i 15 Ugolovnogo kodeksa Rossiiskoi Federatsii. Novosibirsk: Materialy IV studencheskoi mezhdunarodnoi zaochnoi nauchno-prakticheskoi konferentsii, 2012.

7. Nikulin S. Voprosy primeneniya ch. 6 st. 15 UK RF. Ugolovnoe pravo, 2012. - N 5; Mingalimova M. Neyasnost' v prakticheskom primenenii novykh polozhenii Obshchei chasti UK. Zakonnost'. - 2013. - N 3; Vinitskii L., Kubrikova M. Vozmozhno li izmenenie kategorii prestupleniya pri rassmotrenii ugolovnykh del v poryadke gl. 40.1 UPK RF? Zakonnost', 2013. - N 8; Malkov V. Pravo suda na izmenenie kategorii prestupleniya. Zakonnost'. - 2013. - N 11; Trofimova G.A. Rasshirenie granits printsipa sudeiskogo usmotreniya. Rossiiskii sud'ya. - 2014. - N 1. SPS “Konsul'tantPlyus”.

8. Strogovich M. S. Kurs sovetskogo ugolovnogo protsessa: V 2 t. - Moskva: T. I., 1970.

9. Malkov V. P. Pravo suda na izmenenie kategorii prestupleniya. - SPS "Konsul'tantPlyus".

10. Khaidarov A. A. Pravo suda izmenit' kategoriyu prestupleniya na menee tyazhkuyu. - SPS "Konsul'tantPlyus".

11. Gorbatova M., Rusman G. Izmenenie kategorii prestupleniya: problemy pravoprimeneniya i obratnaya sila ugolovnogo zakona. - Ugolovnoe pravo. - 2012. - N 5. 